\title{
ANALYSIS OF THE INFLUENCE OF THE IMPACT SPEED ON THE RISK OF INJURY OF THE DRIVER AND FRONT PASSENGER OF A PASSENGER CAR
}

\section{OCENA WPŁYWU PRĘDKOŚCI ZDERZENIA NA RYZYKO OBRAŻEŃ KIEROWCY I PASAŻERA SAMOCHODU OSOBOWEGO*}

\begin{abstract}
The subject of the analysis was the influence of the speed, at which a personal car hit an obstacle, on the risk of injury of the driver and the passenger sitting in the front seat. With this goal in mind, several hundred of crash tests were analysed, published on the Internet by National Highway Traffic Safety Administration (USA). The analysis focuses on the cases involving a frontal impact of the car on a rigid barrier. For the purpose of assessing the forces acting on a dummy, Head Injury Criterion (HIC $\left.C_{36}\right)$ and Chest Acceleration $\left(C_{A c c}\right.$ ), were applied, calculated on the basis of the resulting acceleration of head and chest of the dummy. Separate analyses were performed for the forces acting on the dummy representing 50-centile man (M50) and 5-centile woman (F5). A statistical analysis of the results of the crash tests was performed in order to determine the typical values of HIC $\mathrm{H}_{36}$ and $C_{A c c}$ factors, as well as the risk of severe injury of the driver and the passenger at a given collision speed. The risk of injury was calculated on the basis of provided in the research literature so-called injury risk curves. It was determined that increasing the speed at which a car hits an obstacle from $25 \mathrm{~km} / \mathrm{h}$ up to $56 \mathrm{~km} / \mathrm{h}$ results in the increase in the risk of severe injury (AIS4) of the driver and the passenger from 2 to $10 \%$. Some functions were proposed, describing the relation between the risk of injury and the velocity of collision.
\end{abstract}

Keywords: road accidents, crash tests, impact speed, risk of injury.

\begin{abstract}
Rozważono wpływ prędkości uderzenia samochodu osobowego w przeszkodę na ryzyko obrażeń kierowcy oraz pasażera na przednim fotelu. W tym celu wykorzystano wyniki kilkuset testów zderzeniowych, udostęnionych w Internecie przez National Highway Traffic Safety Administration (USA). Uwagę skupiono na czołowe uderzenie samochodu w sztywna barierę. Podczas oceny obciażeń manekinów wykorzystano wskaźniki obrażeń głowy $\mathrm{HIC}_{36}$ oraz torsu $C_{A c c}$ które oblicza się na podstawie wypadkowego przyspieszenia działającego na głowę i tors manekina. Oddzielnie rozważono obciażenia manekina reprezentujacego 50-centylowego mężczyznę (M50) oraz 5-centylową kobietę (F5). Przeprowadzono statystyczna ocenę wyników testów zderzeniowych, której celem byto określenie dominujących wartości wskaźników $\mathrm{HIC}_{36}{ }{ }_{C_{A c c}}$ oraz ryzyka ciężkich obrażeń kierowcy i pasażera przy danej prędkości zderzenia. Ryzyko obrażeń obliczono na podstawie dostęnych w literaturze tzw. funkcji ryzyka obrażeń. Ustalono, że zwiększenie prędkości uderzenia samochodu w przeszkodę z $25 \mathrm{~km} / \mathrm{h}$ do $56 \mathrm{~km} / \mathrm{h}$ zwiększa ryzyko ciężkich obrażeń (AIS4) kierowcy i pasażera z 2 do 10\%. Zaproponowano funkcje wiązace ryzyko obrażeń i prędkość zderzenia.
\end{abstract}

Stowa kluczowe: wypadki drogowe, testy zderzeniowe, prędkość zderzenia, ryzyko obrażen.

\section{Introduction}

Speed is a basic operating parameter of a car, taken into account while designing roads and streets, determining the total time of the journey but also the risk of a traffic accident and the severity of its possible results. Legal provisions setting limits to the speed are a common solution to the problem of the abovementioned danger. However, this solution is often inefficient because many drivers violates the limits. In the European Union, 40-50\% of the drivers exceed the speed limit on a given stretch of the road, with $10-20 \%$ of drivers driving at $10 \mathrm{~km} / \mathrm{h}$ or more above the limit [22]. As the research conducted in Poland in 2013-2014 indicate, about 30\% of the drivers drive at more than $10 \mathrm{~km} / \mathrm{h}$ above the speed limit [2]. Improving the measures of supervision results in the decreasing share of the accidents caused by the excessive speed is in the last couple of years, from $31 \%$ in 2007 to $26 \%$ in 2014 . With regard to the number of fatalities it is a change from $47 \%$ to $39 \%$.

When setting the speed limit and deciding on the measures of supervision to be applied, many factors are taken into account, connected with the road geometry and its visibility, the condition of the surface, intensity and structure of the traffic among others. Another important issue is the influence of the speed on the results of the acci- dents $[5,21]$. Event data recorders (EDR), which are gaining popularity among car users, make it easier to examine the relations between the velocity of the collision and the injury to the occupants of the vehicle $[3,4,8,9]$. However, determining the possible injuries on the basis of the measured forces acting on a dummy during a crash test is still a difficult task.

Normative requirements regarding crash tests of the cars usually specify one value of test speed (e.g. ECE UN Regulations No 44, 80, 94 and 95). The results of laboratory tests, assessing the influence of the collision speed on the forces acting on the occupants of the vehicle are rarely published, the apparent reason being the costs of this kind of research. On order to limit the costs, the tests are sometimes conducted with one and the same car hitting the obstacle at several different values of speed. For example, paper [14] presents the results of the research on the forces acting on the driver of a SUV car at the velocity 4,10 and $43 \mathrm{~km} / \mathrm{h}$, and in paper [20] the results are described of a bus at 4, 7 and $30 \mathrm{~km} / \mathrm{h}$. The results of model tests are published more often. Papers $[10,12]$ describe analyses of the forces acting on the model dummies at $70-90 \mathrm{~km} / \mathrm{h}$, which is much more than in the case of typical crash tests $(30-64 \mathrm{~km} / \mathrm{h})$. The results of the research on the influence of the car collision speed on the other variables are used

(*) Tekst artykułu w polskiej wersji językowej dostępny w elektronicznym wydaniu kwartalnika na stronie www.ein.org.pl 
to assess to test the effectiveness of passive safety devices, but also to model the injuries of the driver for the purpose of activating eCall system (automatic notification of the accident) [12] or to assess the costs of traffic accidents [10].

The purpose of the paper is to discuss the assessment of the influence of the car collision speed on the dynamic load on the driver and the passenger sitting in the front seat, in the case of a car hitting a rigid barrier. This kind of tests is used to assess the risk of injury of the occupants of the vehicle. The risk was calculated on the basis of so-called injury risk curves presented in the research literature, functions which take into account the forces acting on the head and the chest of the dummies. The analysis involves the results of the crash tests published on the Internet by $\mathrm{Na}$ tional Highway Traffic Safety Administration [24]. The results of the assessment of the risk of injury, performed on the basis of the laboratory tests, are applied to the data on the car accidents. The work was aimed at identifying the vehicle design and operation factors that are decisive for the loads on vehicle passengers during a road accident and for the necessity of reducing the loads to a minimum.

\section{Collision speed and the results of the car accident}

The results of a traffic accident depend on a variety of factors connected with the variables of movement and the kind of the vehicle, properties of the road and its surroundings (type of the obstacle) and the human factors (anthropometric features, age, health). The main parameters taken into account are the speed at which the vehicle hits the obstacle (or another car), the direction of impact (frontal, side) or the type of the protective devices used in the car. Another important features include the weight and height of the occupant of the car, his or her place in the car, and position on the seat $[15,25,28]$. A number of tests indicate that the effectiveness of the protective devices depends on the manner of use (e.g. proper positioning and tension of the seat belt, proper infant restraint) [29]. This is why the assessment of the influence of the impact speed (which is one of the many operating factors) on the results of the collision requires that the other factors are constant throughout the tests.

In the assessment of the injuries during the traffic accidents, a six-degree scale called AIS (Abbreviated Injury Scale) is often used, where specific kinds of injuries were assigned a certain level, expressed as a number. The higher the number, the greater the threat to life. For example, AIS3 + denotes injuries of AIS3 degree or higher. Maximum AIS Scale (MAIS) is used to describe the condition of the injured with multiple injuries [17].

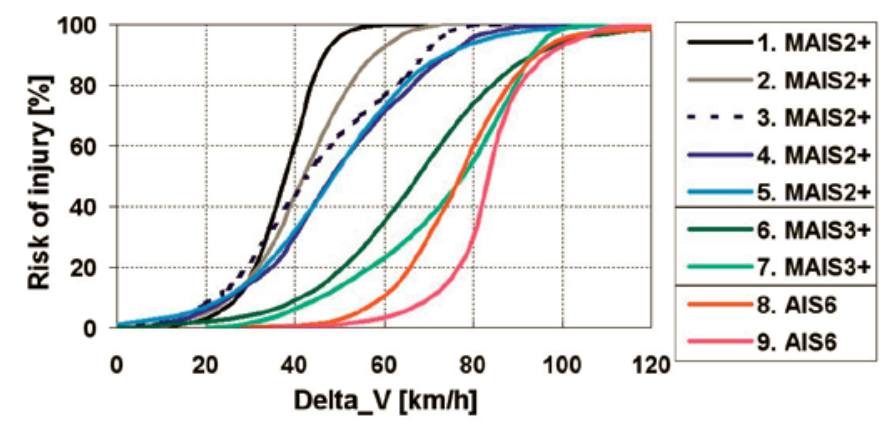

Fig. 1. Risk of injury of the driver and the passenger on the front seat during a frontal impact (the lines are described in Table 1)
On the basis of the analysis of the data on the traffic accidents, statistical models are developed, making it possible to assess the influence of the impact speed on the risk of injury of the occupants of the vehicle. On the basis of several research papers from 2003-2012 [4, $8,9,16,18,23]$, injury risk curves were calculated for the occupants of the vehicle (logistic regression), presented in Figure 1, regarding the cases of frontal impact (overlap above $25 \%$, impact angle within $\pm 30^{\circ}$ ). The lines on the chart denote the risk of MAIS2+, MAIS3+ and AIS6 injury, the last one being a fatal injury. The injuries are classified as MAIS2 in case of e.g. concussion with a loss of consciousness, jaw or basal skull fracture, lung or heart contusion, fracture of 4 and more ribs at one side $[12,17,21]$. Some data on the accidents involved in the analysis presented in Figure 1 are presented in Table 1. The data consider the driver and the passenger on the front seat (men and women in various age), with their seatbelts fastened, during a frontal impact of a passenger car, respectively: with another personal car (C-C) with a truck (C-T), or with an obstacle (C-O).

The change in vehicle velocity over the duration of the crash event Delta_V was determined on the basis of the data from the devices recording the variables of the movement of the cars (CPR - Crash Pulse Recorder, EDR - Event Data Recorder), mounted in some cars even since 1992 [9]. During a frontal crash impact involving two cars, A and $\mathrm{B}$, moving at $\mathrm{V}_{\mathrm{A}}$ and $\mathrm{V}_{\mathrm{B}}$ speed, respectively, the change in vehicle velocity depends on their mass, $\mathrm{m}_{\mathrm{A}}$ and $\mathrm{m}_{\mathrm{B}}$, respectively, according to the principle of the conservation of linear momentum [21].

$$
\begin{aligned}
& \text { Delta_ } V_{A}=\left(V_{A}+V_{B}\right) \cdot m_{B} /\left(m_{A}+m_{B}\right) \\
& \text { Delta_ } V_{B}=\left(V_{A}+V_{B}\right) \cdot m_{A} /\left(m_{A}+m_{B}\right)
\end{aligned}
$$

Assuming that the duration of the impact phase is the same for both of the vehicles (about $0.1-0.2 \mathrm{~s}$ ), Delta_V determines the deceleration of a car, which in turn determines the value of inertial forces acting on the car and its occupants, therefore determining the severity of the crash. As we can infer from (1), the deceleration is higher in the case of lighter cars. If the weight of the cars is equal, Delta_ $V_{A}=$ Delta_ $V_{B}=0,5 \cdot\left(V_{A}+V_{B}\right)$. If a car hits a stationary, non-deformable obstacle, at speed V, Delta_V $\approx V$.

The results presented in Figure 1 confirm that there is a strong dependency between the risk of injuries and Delta_V. As for MAIS2+ injuries, it was proved that a frontal impact involving a passenger car and a lorry is more dangerous, than in case of the same type of impact involving two passenger cars (lines no 1 and 2). Important observations include: 
- quite a high difference between the shape of the lines referring to a given degree of injuries (with the exception of lines 4 and 5, where the functions of MAIS2+ risk, determined on the basis of research on the accidents in Sweden and USA, are similar);

- risk lines 6 and 7 (MAIS3+) are quite close to lines 8 and 9 (AIS6), that is in the place where the lines are expected regarding AIS4 and AIS5 injuries;

- similarities between lines 7 and 8 when Delta_V>70 $\mathrm{km} / \mathrm{h}$, despite the fact that the lines refer to different degrees of injury (MAIS3+ and AIS6).

These results show that it is difficult to develop a function (model) that would describe the dependence of the risk of injuries on the speed of collision, and the small number of accidents (Table 1) results in a low statistical representativeness of those functions. The confidence intervals for some of the abovementioned risk functions are presented in $[4,16]$.

The differences in the risk lines presented in Figure 1, referring to the same degree of injury, may result from the factors other than the abovementioned criteria of similarity of accidents. For example, the accidents analysed include cars manufactured in different years, and therefore with different passive safety systems. We know that all the people injured had their seatbelts fastened but there is no information on the construction of those belts (lock tensioners, force limiters), which has a very significant effect on the forces acting on the person protected and therefore on the injuries [27]. The age and the anthropometric features of the driver and of the passenger are also important $[3,13]$.

\section{Indicators of the risk of injury}

The injuries of the driver and the passengers during a traffic accident are caused by dynamic loads, resulting by stopping the car suddenly. The loads are measured in the crash tests usually as accelerations and forces acting on the various parts of the dummy. Further analysis focuses on the acceleration of the head and the chest (torso) of the dummies, representing a 50centile man (M50) and a 5-centile woman (F5). Two indicators were applied:

- $\mathrm{HIC}_{36}$, Head Injury Criterion, calculated

for a time interval of up to $15 \mathrm{~ms}$;

$-C_{A c c}$, maximum resultant torso acceleration [g], acting for a period of at least $3 \mathrm{~ms}$.

$\mathrm{HIC}_{36}$ indicator is calculated on the basis of the acceleration of the head and time of the acceleration $[1,21]$ :

$$
H I C_{36}=\max \left[\frac{1}{\left(t_{2}-t_{1}\right)} \int_{t_{1}}^{t_{2}} a_{H}(t) d t\right]^{2,5} \cdot\left(t_{2}-t_{1}\right)
$$

where:

$a_{H}(t) \quad-$ resultant acceleration of the centre of the head [g] (CFC100 filtration), calculated on the basis of the component accelerations, measured in three mutually perpendicular directions; $\Delta t=t_{2}-t_{1} \leq 0.036 \mathrm{~s}-$ length of time [s] with the highest values of $a_{H}(t)$.

$C_{A c c}$ indicator is calculated from the resultant chest acceleration $a_{C}(t)$, while its components, measured in three mutually perpendicular directions, were filtered with $C F C 180$ [1]. Figure 2 presents an exemplary resultant acceleration of head and chest. The blue lines denote
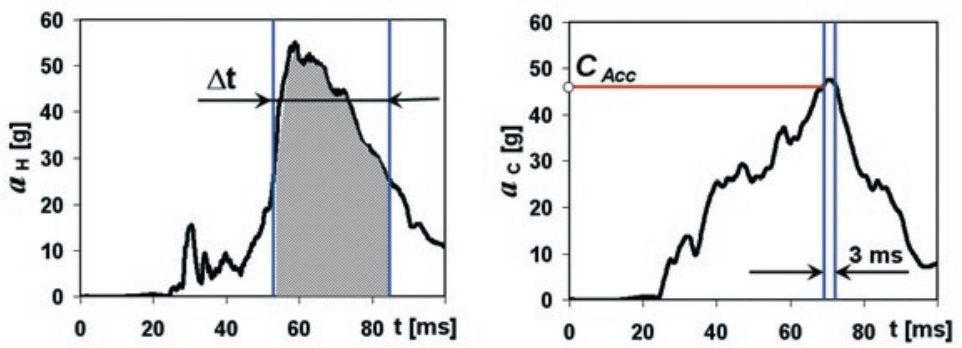

Fig. 2. Resultant acceleration of the head and chest of the dummy (example)

the time span where the indicators are calculated. The hatched area under $a_{H}(t)$ line denotes the integral of the expression (2).

The values of $H_{I C}$ and $C_{A c c}$ indicators are used to calculate the risk (probability) of injuries of the head and chest. Injury risk curves for severe injuries (AIS4+) of the head and chest $[1,11,25]$ were applied:

$$
\begin{gathered}
P_{\text {head }}(A I S 4+)=\left\{1+\exp \left[5,02-0,00351 \cdot H I C_{36}\right]\right\}^{-1} \\
P_{\text {chest }}(A I S 4+)=\left\{1+\exp \left[5,55-0,0693 \cdot C_{A c c}\right]\right\}^{-1}
\end{gathered}
$$

Risk curves are presented in Figure 3, denoting the risk in percentage. The limit values for M50 and F5 dummies are, respectively, $H I C_{36}=1000$ i $C_{A c c}=60 \mathrm{~g}[1,21]$. The risk of severe injury AIS4+ b)

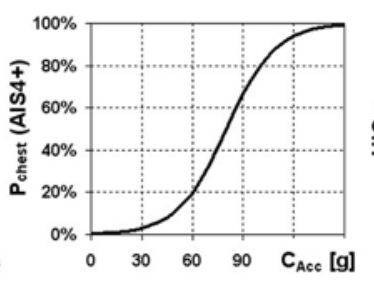

c)

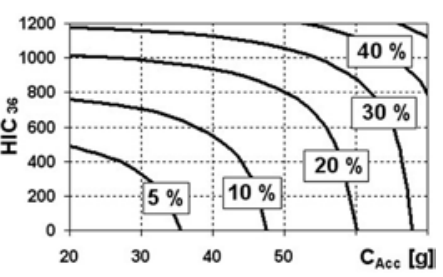

Fig. 3. Risk of severe injury (AIS4+) of head and chest of M50 and F5 dummies ( $a$ and b) and the risk curves $P_{\text {comb }}(c)$

of head and chest does not exceed $20 \%$ in this case, but it increases rapidly when the limit values are exceeded (Figure $3 a, b$ ). The same functions hold for M50 and F5 dummies.

The loads at head and chest usually do not change to such a degree when the conditions of the crash test are changed, e.g. when the speed of the collision is changed. This is why combined injury probability criterion $P_{\text {comb }}$ was used to assess the loads on the dummies $[1,11]$ :

$$
P_{\text {comb }}=1-\left(1-P_{\text {head }}\right) \cdot\left(1-P_{\text {chest }}\right)=P_{\text {head }}+P_{\text {chest }}-P_{\text {head }} \cdot P_{\text {chest }}
$$

In the further part of the analysis, $H I C_{36}=f\left(C_{A c c}\right)$ chart was applied, presented in Figure $3 \mathrm{c}$, where the lines indicate the values of $H I C_{36}$ and $C_{A c c}$, at which the values of $P_{c o m b}(A I S 4+)$ indicator (risk of severe injury) are 5, 10, 20, 30 and $40 \%$, respectively.

\section{Selection of the crash tests for the analysis}

For the purpose of the analysis of the influence of the impact speed on the dynamic load on the driver and on the passenger, the results of crash tests published in the Internet by National Highway Traffic Safety Administration were applied [24]. NHTSA database includes the results of over 7000 crash tests of the cars from 1965-2016, conducted under various conditions (different types of impact, barrier 

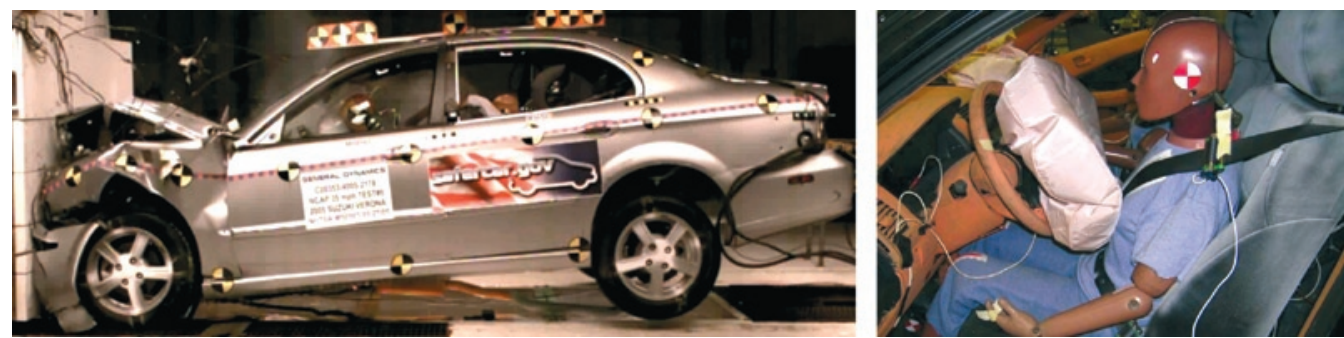

The passenger cars have different construction of the frontal crumple zone, which significantly influences the process of deformation of the zone upon hitting the obstacle, and therefore also the deceleration of the car [26]. This is why the further division of the crash tests into the categories was based on the type of the car. The greatest number was that of „classic" cars (61\% of the tests, weight of the car during the crash test: $932-2562 \mathrm{~kg}$ )

types, velocity of collision etc.), with the special focus on the frontal impact of a car on a rigid, plain barrier, placed perpendicularly to the direction of the drive (Figure 4).

Crash tests of the cars produced in 1990-2010 were chosen for the analysis, where the dummies placed on the front seats had their seatbelts fastened, and were protected with a front airbag (Figure 4). The cars manufactured more recently were omitted because, for the records from $2011 \mathrm{on}$, NHTSA database includes the values $H_{15}(\Delta t \leq 15 \mathrm{~ms})$, which replaced $H I C_{36}(\Delta t \leq 36 \mathrm{~ms})$.

The speed with which the car hits the barrier is only one of many factors influencing the load on the dummies. This is why for the purpose of further analysis the results of the crash tests were divided into several groups in such a manner as to limit the influence of the other factors on the result of the assessment performed for the purpose of the analysis described in the paper. The first two groups of results (data) were obtained with grouping the crash tests according to the car's manufacturing year (standard of the used passive safety systems):

- the models manufactured in 1990-1999;

- the models manufactured in 2000-2010.

The indicators connected with the driver and the passenger were analysed separately due to the fact that the loads on the same dummies may differ significantly if placed on different seats in the car $[25,28]$. For example, the values of $H_{I C} C_{36}$ and $C_{A c c}$ indicators in Figure 5, regarding M50 dummy placed on the driver and passenger seat were compared (422 tests, cars from 2000-2010, speed $56 \mathrm{~km} / \mathrm{h}$ ). The differences in $H I C_{36}$ for the driver and the passenger were as following:

- not more than $\pm 10 \%$ in 111 tests $(26 \%$ of the results are between the red lines):

- more than $20 \%$ in 211 tests ( $50 \%$ of the tests).

The differences in $C_{A c c}$ for the driver and the passenger were as following:

- not more than $\pm 10 \%$ in 274 tests $(65 \%$ of the results are between the red lines):

- more than $20 \%$ in 31 tests ( $7 \%$ of the tests).
- a category including hatchback, sedan, coupe, kombi and convertible cars. Vehicles of that category have similar construction of the integral body. Moreover, the following types of cars are included:

- utility vehicles, with a reinforced chassis, drive usually $4 \times 4$ ( $20 \%$ of the tests, weight $1298-2917 \mathrm{~kg})$;

- pickups, with a frame chassis $(11 \%$ of the tests, weight 1447 $3054 \mathrm{~kg}$ );

- vans ( $8 \%$ of the tests, weight $1661-2721 \mathrm{~kg}$, including minivans).

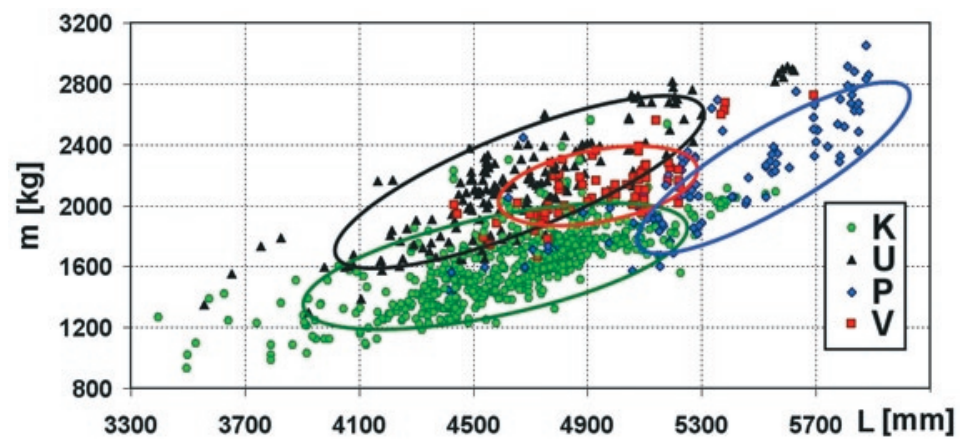

Fig. 6. Comparison ofmass ( $m$ ) and length (L) of the passengercars (according to [24]): $K$-classic; $U$-utility vehicles; $P$ - pickups; $V$-vans

In order to present the differences between the four types of cars, their weights and length were compared in Figure 6.

Further analysis includes:

- 788 tests with Hybrid III M50 dummies on the front seats (in 55 tests from 1990-1995, there were Hybrid II dummies on the passenger seat);

- 125 tests with Hybrid III F5 dummies on the front seats.

Table 2 provides information on the number of tests at a given collision speed, with regard to the manufacturing year and type of the car (acc. to NHTSA classification), as well as the kind of a dummy. The greatest number of tests were performed at nominal speed with which the car hit the obstacle: 40, 48 and $56 \mathrm{~km} / \mathrm{h}(25,30$ and 35 miles per hour, respectively), where the usual speed in the case of M50 dummy was usually $56 \mathrm{~km} / \mathrm{h}$, whereas in the case of F5 it was usually $48 \mathrm{~km} / \mathrm{h}$. The real value of the speed at which the car hit the obstacle was usually within the range of $\pm 1 \mathrm{~km} / \mathrm{h}$ from the nominal value.

\section{Preliminary assessment of the influence of the impact speed on the loads of a dummies}

At this stage of the analysis, all types of cars were taken into account (Figure 6). In Figure 7, the values of $\mathrm{HIC}_{36}$ and $C_{A c c}$ were presented with regard to the speed at which the car hit the barrier. The values refer to M50 and F5 dummies placed
Fig. 5. Comparison of $\mathrm{HIC}_{36}$ and $\mathrm{C}_{\text {Acc }}$ indicators, calculated for M50 dummy placed on the driver's seat (D) and on the passenger's seat (P); cars from 2000-2010 (56 $\mathrm{km} / \mathrm{h}$ ) 
Table 2. Number of the crash tests included in the analysis ( $K$ - classic, $U$ - utility vehicles, $P$ - pickups, $V$-vans and minivans)

\begin{tabular}{|c|c|c|c|c|c|c|c|c|c|c|c|}
\hline \multirow{2}{*}{ Impact speed } & \multirow{2}{*}{$\begin{array}{c}\text { Manufacturing } \\
\text { year of a car }\end{array}$} & \multicolumn{2}{|c|}{$\mathrm{K}$} & \multicolumn{2}{|c|}{ U } & \multicolumn{2}{|c|}{$\mathrm{P}$} & \multicolumn{2}{|c|}{ V } & \multicolumn{2}{|c|}{ Total } \\
\hline & & M50 & F5 & M50 & F5 & M50 & F5 & M50 & F5 & M50 & F5 \\
\hline$<40 \mathrm{~km} / \mathrm{h}$ & $2000-2010$ & 2 & 3 & \multicolumn{6}{|c|}{0} & 2 & 3 \\
\hline \multirow{2}{*}{$40 \mathrm{~km} / \mathrm{h}$} & 1990-1999 & 0 & 1 & \multicolumn{6}{|c|}{0} & 0 & 1 \\
\hline & $2000-2010$ & 0 & 7 & 0 & 0 & 0 & 1 & 0 & 2 & 0 & 10 \\
\hline \multirow{2}{*}{$48 \mathrm{~km} / \mathrm{h}$} & 1990-1999 & 28 & 30 & 9 & 1 & 3 & 4 & 6 & 3 & 46 & 38 \\
\hline & $2000-2010$ & 40 & 37 & 2 & 3 & 3 & 5 & 2 & 4 & 47 & 49 \\
\hline \multirow{2}{*}{$56 \mathrm{~km} / \mathrm{h}$} & 1990-1999 & 171 & 2 & 41 & 0 & 29 & 0 & 30 & 0 & 271 & 2 \\
\hline & $2000-2010$ & 218 & 16 & 127 & 0 & 50 & 2 & 27 & 4 & 422 & 22 \\
\hline \multicolumn{2}{|c|}{ Total } & 459 & 96 & 179 & 4 & 85 & 12 & 65 & 13 & 788 & 125 \\
\hline
\end{tabular}

on the driver's seat. What is interesting, there was a huge dispersion of the values of the indicators at a given speed, irrespectively of the cars' year of production and the type of the dummy. For example, the values of $\mathrm{HIC}_{36}$ when the car hit the barrier $56 \mathrm{~km} / \mathrm{h}$ speed for M50 dummy were within the range of 176-1079 (cars from 2000-2010). This result shows that the effectiveness of protective devices used in cars varies greatly. The effect of the speed at which the car hits the barrier is more visible in case of
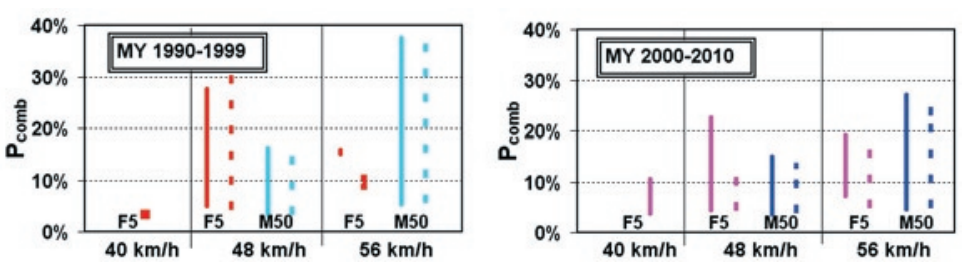

Fig. 8. Influence of the impact speed on the value of risk $P_{\text {comb }}(A I S 4+)$; (solid lines driver; dashed lines - passenger)
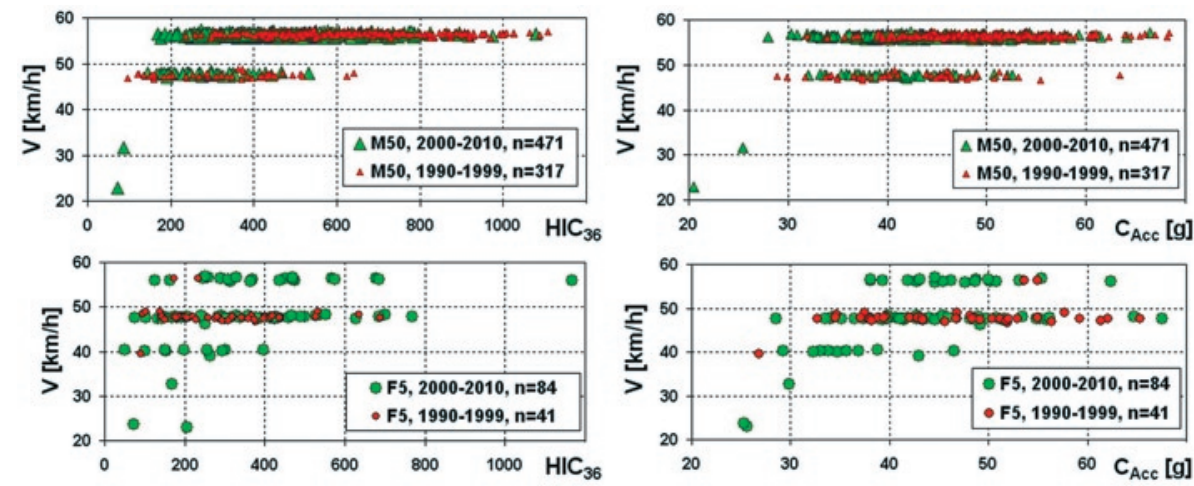

Fig. 7. Influence of the impact speed on the values of $H I C_{36}$ and $C_{A c c}$ for M50 and F5 dummies placed on the driver's seat

Table 3. Ranges of $\mathrm{HIC}_{36}$ and $\mathrm{C}_{\text {AcC }}$ as well as $P_{\text {head }} P_{\text {chest }} P_{\text {comb }}$ risk factors

\begin{tabular}{|c|c|c|c|c|c|c|c|c|c|c|}
\hline \multirow{3}{*}{$\begin{array}{c}\text { Dummy } \\
\text { MY } \\
\text { V [km/h] }\end{array}$} & \multicolumn{4}{|c|}{ M50 } & \multicolumn{6}{|c|}{ F5 } \\
\hline & \multicolumn{2}{|c|}{ 1990-1999 } & \multicolumn{2}{|c|}{ 2000- 2010} & \multicolumn{3}{|c|}{ 1990-1999 } & \multicolumn{3}{|c|}{$2000-2010$} \\
\hline & 48 & 56 & 48 & 56 & 40 & 48 & 56 & 40 & 48 & 56 \\
\hline$n$ & 44 & 265 & 48 & 417 & 1 & 36 & 2 & 10 & 46 & 20 \\
\hline \multicolumn{11}{|c|}{ Ranges of the indicators calculated for the dummy on the driver seat } \\
\hline$H I C_{36}$ & $90-518$ & $238-1088$ & $144-532$ & 169-894 & 90 & $96-636$ & $174-234$ & $51-396$ & $75-628$ & $126-686$ \\
\hline$C_{A C C}[g]$ & $27-55$ & $32-71$ & $32-53$ & $28-61$ & 27 & $33-65$ & $54-55$ & $29-47$ & $28-56$ & $38-55$ \\
\hline$P_{\text {head }}[\%]$ & $1-4$ & $1-23$ & $1-4$ & $1-13$ & 1 & $1-6$ & 1 & $1-3$ & $1-6$ & $1-7$ \\
\hline$P_{\text {chest }}[\%]$ & $2-15$ & 3-35 & $3-13$ & $3-21$ & 2 & $4-26$ & $14-15$ & $3-9$ & $3-16$ & $5-15$ \\
\hline$P_{\text {comb }}[\%]$ & $3-16$ & $5-38$ & $5-15$ & $5-27$ & 3 & $5-28$ & $15-16$ & 4-11 & $5-23$ & 7-19 \\
\hline \multicolumn{11}{|c|}{ Ranges of the indicators calculated for the dummy on the passenger seat (next to the driver) } \\
\hline$n^{*}$ & 38 & 192 & 43 & 417 & 0 & 34 & 2 & 10 & 45 & 18 \\
\hline$H I C_{36}$ & $80-573$ & $181-1163$ & $101-536$ & 214-902 & - & $69-723$ & $174-261$ & $93-298$ & $91-678$ & 196-712 \\
\hline$C_{A c C}[g]$ & $26-53$ & $35-64$ & $28-50$ & $29-59$ & - & $32-67$ & $43-47$ & $31-44$ & $30-49$ & $30-52$ \\
\hline$P_{\text {head }}[\%]$ & $1-5$ & $1-28$ & $1-4$ & $1-14$ & - & $1-8$ & $1-2$ & $1-2$ & $1-7$ & $1-7$ \\
\hline$P_{\text {chest }}[\%]$ & $2-13$ & $4-24$ & $3-11$ & 3-19 & - & $3-29$ & $7-9$ & $3-7$ & $3-11$ & $3-13$ \\
\hline$P_{\text {comb }}[\%]$ & 4-15 & $6-37$ & $4-14$ & $5-25$ & - & $5-31$ & $9-10$ & $5-9$ & $5-13$ & $5-18$ \\
\hline
\end{tabular}
the driver and the passenger calculated on the basis of (3)-(5).

The number of the tests with a passenger $\left(n^{*}\right)$ is smaller than the number of the tests with the driver $(n)$ because the results were omitted that do not meet the abovementioned similarity criteria of the conditions of tests, e.g. there was no air cushion for the passenger in some of the older car models, or there was a different dummy on the passenger seat.

There was a significant range, that is the difference between the minimum and maximum value, for $H I C_{36}$ and $C_{A c c}$, at a given collision speed, which makes it more difficult to analyse the impact of the speed on head and chest inju-
M50 dummy load that in the case of F5. The values of $H I C_{36}$ and $C_{A c c}$ for F5 dummy are within a similar range at 48 and $56 \mathrm{~km} / \mathrm{h}$ (cars from 2000 2010). As for M50 dummy, the maximum values of $H I C_{36}$ at $56 \mathrm{~km} / \mathrm{h}$ are about two times higher than at $48 \mathrm{~km} / \mathrm{h}$. The maximum values of $C_{A c c}$ for M50 dummy at $56 \mathrm{~km} / \mathrm{h}$ are about $30 \%$ higher than at $48 \mathrm{~km} / \mathrm{h}$.

In further analysis of the influence of the impact speed on the injuries of the occupants of the vehicle, the results of 24 tests were omitted where the values of $H_{I C} C_{36}$ and $C_{A c c}$ indicators at a given collision speed were significantly higher than in the other cases (cf. Fig. 7). Table 3 presents the ranges of $H_{I C} C_{36}$ and $C_{A c c}$ indicators and the risk

of severe injury (AIS4+) $P_{\text {head }}, P_{\text {chest }}, P_{\text {comb }}$ of 
ries. Minimum values of head injury indicator are usually $H_{I C}<900$ and $C_{A c c}<60 \mathrm{~g}$ for the chest. The risk of severe injury (AIS4+) in these cases is not higher than $14 \%$ (head) and $20 \%$ (chest). The load on the chest determines the total risk of injury $P_{\text {comb }}$, irrespective of the speed of the car.

In Figure 8, collision speed and the risk of severe injury $P_{\text {comb }}$ are juxtaposed. Taking into account the results for the two dummies (M50 and F5) placed on the driver's seat and on the passenger's seat, the following ranges of the risk of injury were determined:

- cars manufactured in 1990-1999 - cars manufactured in 2000-2010

$$
\begin{array}{ll}
P_{\text {comb }}=4 \div 31 \% \text { at } 48 \mathrm{~km} / \mathrm{h} ; & P_{\text {comb }}=4 \div 11 \% \text { at } 40 \mathrm{~km} / \mathrm{h} \text { (F5 only); } \\
P_{\text {comb }}=5 \div 38 \% \text { at } 56 \mathrm{~km} / \mathrm{h} ; & P_{\text {comb }}=4 \div 23 \% \text { at } 48 \mathrm{~km} / \mathrm{h} ; \\
& P_{\text {comb }}=5 \div 27 \% \text { at } 56 \mathrm{~km} / \mathrm{h} .
\end{array}
$$

\section{Statistical analysis of the influence of the impact speed on the loads on the dummies}

\subsection{The scope of the analysis}

A more detailed analysis of the influence of the speed at which the car hit the obstacle on the loads and injury risk of the occupants of the car was performed on the basis of the statistical analysis of the values of $H I C_{36}$ and $C_{A c c}$ indicators and values of risk factors $P_{\text {head }}, P_{\text {chest }}$, $P_{\text {comb }}$, applied as random variables. In order to analyse the properties of the probability distribution, histograms were prepared. On the basis of the number of crash tests $n$ and the range $R$ of a given indicator, the values $x_{1}, x_{2}, \ldots, x_{n}$ were grouped into $k$ intervals (bins) with the length of $h$ (bin interval), taking into account $[6,7]$ :

$$
k \approx \sqrt{n} ; k \leq 5 \log (n) ; h \approx \frac{R}{k}
$$

where: $\bar{x}$ - arithmetic mean, $M e-$ median, $s$ - standard deviation, $\mu_{4}$ - fourth moment about the mean.

The asymmetry coefficient $A s=0$ for symmetric distribution $(\bar{x}=M e=M o), A s<0$ for left-skewed distribution $(M o>M e>\bar{x})$ and $A s>0$ for right-skewed distribution $(M o<M e<\bar{x}$ ). The higher the absolute value of the asymmetry coefficient, the stronger the asymmetry of distribution. Kurtosis $K u>3$ and $K u<3$ characterises distribution patterns with more, or less concentration than in the case of normal distribution, for which $K u=3$ [6].

\subsection{Effect of the year of production, type and weight of the car on the $\mathrm{HIC}_{36}$ and $\mathrm{C}_{\mathrm{Acc}}$}

In point 5, the influence of the impact speed on the values of $H I C_{36}$ and $C_{A C c}$ indicators was analysed, separately for the cars from 19901999 and from 2000-2010. At this stage, it was analysed whether there may be a relation between the type and the weight of the car and the high dispersion of the values of $H I C_{36}$ and $C_{A c c}$ indicators at a given speed of collision.

Figure 9a presents the values of $H I C_{36}$ and $C_{A c c}$ indicators for M50 dummy (a driver) in classic cars. The values of $H I C_{36}$ and $C_{A c c}$ indicators were juxtaposed with the injury risk curves (cf. Fig. 3c). A clear difference between the loads on the dummies in case of older and newer cars is confirmed by the distribution functions of the risk of injury $P_{c o m b}$.

In Figure 9b, the values of $H I C_{36}$ and $C_{A c c}$ are presented for M50 dummy (the driver) in the following types of cars: classic (K), utility vehicle (U), pick-ups (P) and vans (V) from 2000-2010. Classic cars, which are the most numerous, are additionally divided into four groups, each of different weight (Fig. 9c). Risk distribution $P_{\text {comb }}$, expressed as a distribution function $F\left(P_{\text {comb }}\right)$, are similar both for differ-
In this manner, every $i^{\text {th }}$ bin was assigned $n_{i}$ number of indicators (number of the elements in a given bin) and the relative number of elements $p_{i}$ (frequency), cumulated number of elements $c_{i}$, and the distribution function $F$ in the upper limits of $x_{i}^{+}$bins:

$$
p_{i}=\frac{n_{i}}{n} ; c_{i}=\sum_{j=1}^{i} n_{j}, \quad \mathrm{i}=1,2, \ldots, \mathrm{k} ; F\left(x_{i}^{+}\right)=\frac{c_{i}}{n}
$$

On the basis of the histograms, mode was calculated [6]:

$$
M o=x_{m}^{-}+h \cdot \frac{n_{m}-n_{m-1}}{2 n_{m}-n_{m-1}-n_{m+1}}
$$

where: $\mathrm{m}$ - number of the bin with the greatest number of elements; $x_{i}^{-}, n_{m}$ - lower limit and number of elements of the bin where the mode is located.

The coefficient of skewness $A s$ and kurtosis $K u$ was used to assess asymmetry and flattening (concentration) of the analysed patterns of distribution [6]:

$$
A s=\frac{\bar{x}-M e}{s} ; K u=\frac{\mu_{4}}{s^{4}}
$$
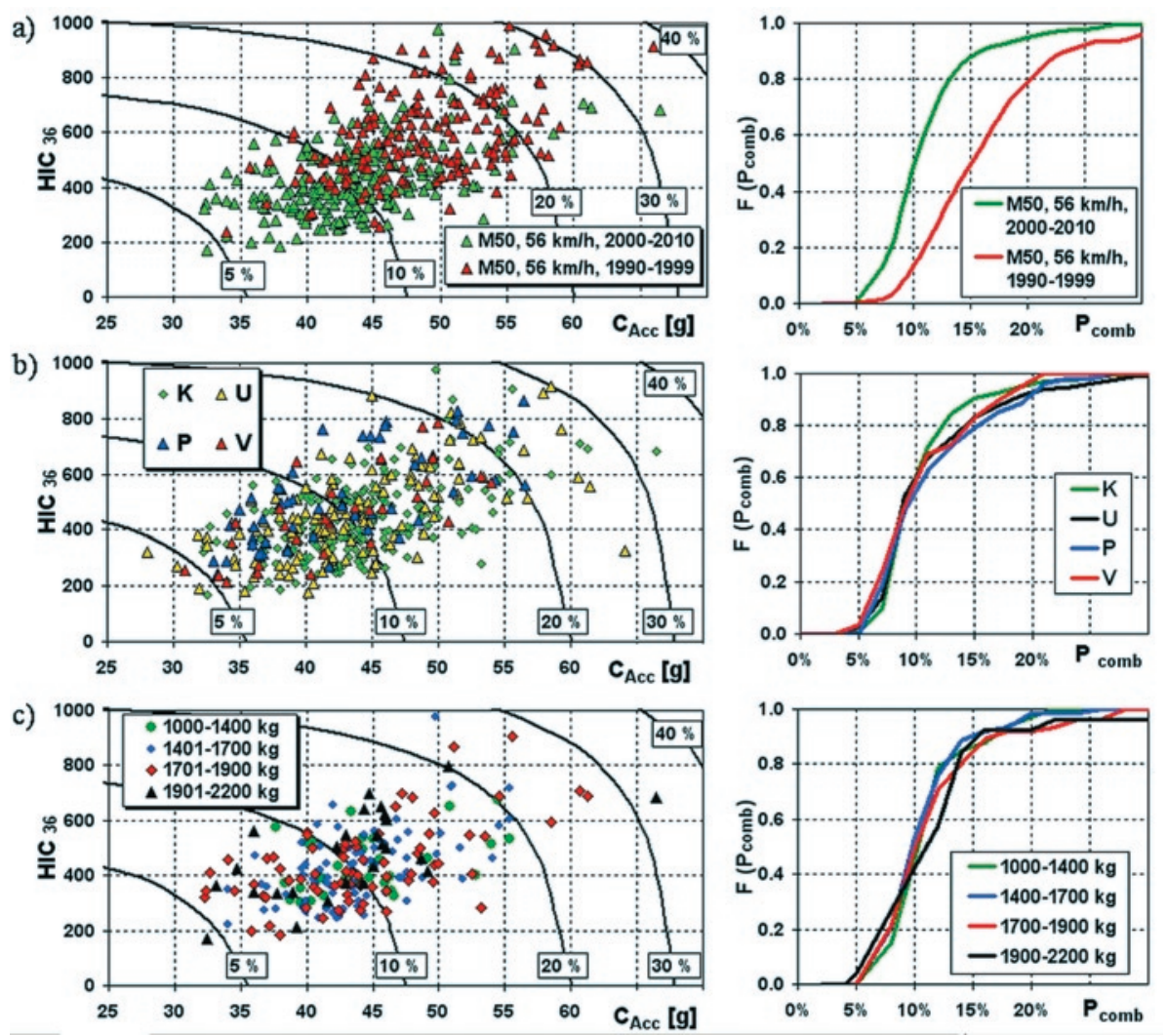

Fig. 9. $H I C_{36}$ and $C_{A c c}$ indicators and the distribution functions of the injury risk $P_{\text {comb }}(A I S 4+)(M 50,56$ $\mathrm{km} / \mathrm{h}$ ); a) cars from 1990-1999 and 2000-2010; b) various types of cars from 2002-2010; c) different values of weight of classic cars (C) from 2000-2010. 

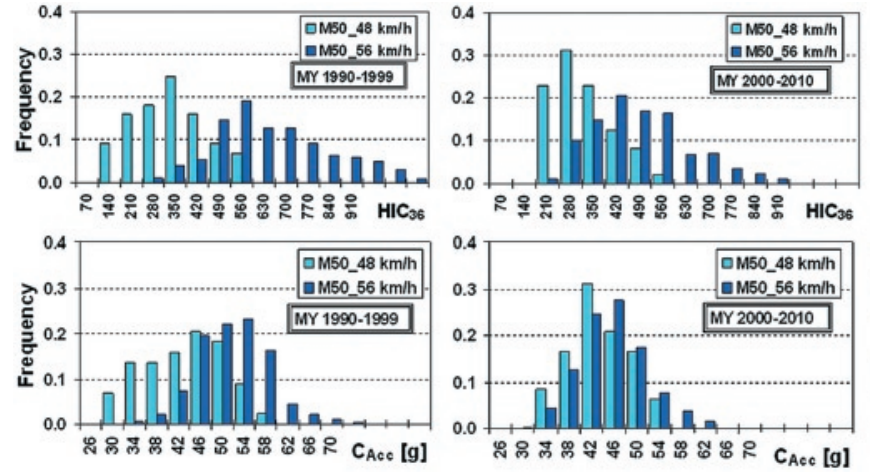

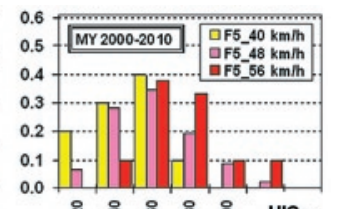

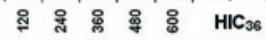

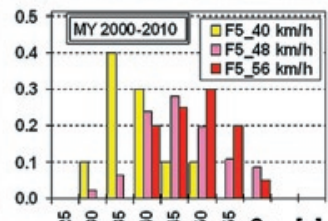

눙

Fig. 10. Histograms of the frequency of $\mathrm{HIC}_{36}$ and $C_{A c c}$ indicators for the dummies on the driver's seat; M50 (48 and $56 \mathrm{~km} / \mathrm{h})$ and $F 5(40,48$ and $56 \mathrm{~km} / \mathrm{h})$
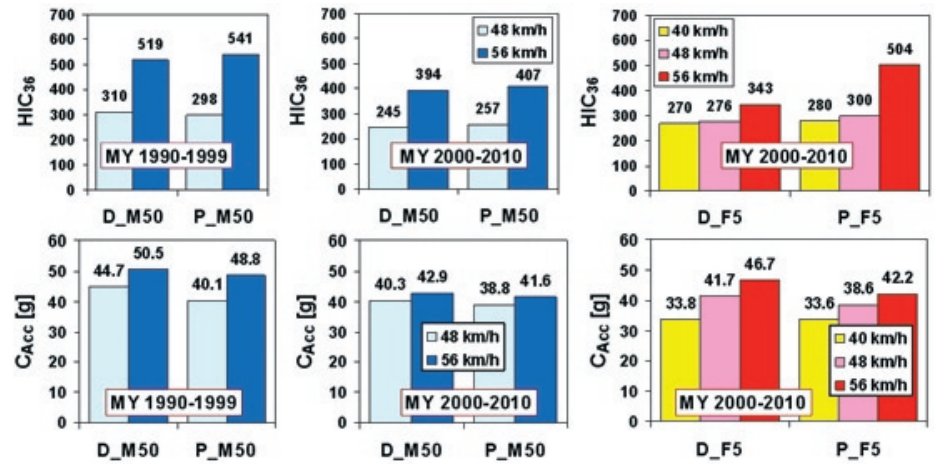

Fig. 11. Mode values of $\mathrm{HIC}_{36}$ and $\mathrm{C}_{\text {Acc }}$ indicators (M50 and F5) for the driver $(D)$ and for the passenger $(P)$ in case of a car hitting the obstacle at 40, 48 and $56 \mathrm{~km} / \mathrm{h}$

ent types of cars and for different weight of classic cars. Therefore, no significant relation was discovered between the type or weight of the car and the distribution of $H I C_{36}$ and $C_{A c c}$ indicators.

On the basis of the above findings, the crash tests were divided into 14 groups ( 7 with the driver and 7 with the passenger), listed above in Table 3 ( 8 groups of the tests with M50 dummy and 6 groups of the tests with F5 dummy). Due to a small number of tests involving Table 4. Values of the parameters describing the properties of risk $P_{\text {comb }}$ distribution the cars from 1990-1999 and F5 dummy, at 40 and $56 \mathrm{~km} / \mathrm{h}$, they were omitted in the further analysis.

\subsection{Effect of the impact speed on the modes of $H I C_{36}$ and $C_{A c c}$ indicators}

The histograms of $H_{I} C_{36}$ and $C_{A c c}$ indicators regarding the loads on the dummies on the driver's seat are presented in Figure 10 (similar distributions were prepared for the passenger). On the abscissa axis, there are values of the upper limits of $x_{i}^{+}$bins. The frequency $p_{i}$ is located on the axis of ordinates (7). The number of elements in the tests was presented above in Table 3. On the basis of (6), bin intervals were applied $h_{H I C}=70$ and $h_{C A C C}=4 \mathrm{~g}$ for the indicators regarding M50 dummy, as well as $h_{H I C}=120$ and $h_{C A c c}=5 \mathrm{~g}$ for the indicators regarding F5 dummy.

On the basis of the analysis of the measures of location, shape and dispersion of the distribution patterns analysed, described in point 6.1, it was determined that the distribution of $H I C_{36}$ and $C_{A c c}$ indicators has a very weak $(|A s|<0,2)$ right-side skewness $(A s>0$, that is $\bar{x}>M o$ ), and concentration lower than in the case of normal distribution (usually $K u \in(1,7 ; 2,9)$, and only for 2 groups $K u>3$ ). Due to the asymmetry of the distribution of the $H_{I C} C_{36}$ and $C_{A c c}$ indicators, mode values $M o$ were applied to describe the maximum of their density functions (Fig. 11).

Increase in the impact speed of the car from 48 to $56 \mathrm{~km} / \mathrm{h}$ has a greater influence on the increase in the mode value of $\mathrm{HIC}_{36}$ than $C_{A c c}$. On the basis of dependencies (3) and (4), it was determined that such an increase in speed results in the increase in mode value of the risk of severe injury of head (from 2 to $4 \%$ ) and chest (from 5-6\% to $7-11 \%)$.

It was proved that the increase in the impact speed has a greater influence on the loads on M50 dummy in case of older cars (cf. 9a and 11). Moreover, the mode values of $H I C_{36}$ and $C_{A c c}$ indicators for M50 dummies on the driver's and passenger's seat are similar at a given speed. However, at $56 \mathrm{~km} / \mathrm{h}$, the mode values of $\mathrm{HIC}_{36}$ indicator are

\begin{tabular}{|c|c|c|c|c|c|c|c|c|c|c|c|c|c|c|}
\hline \multirow{4}{*}{$\begin{array}{c}\text { Dummy } \\
\text { Place } \\
\text { MY } \\
\text { V [km/h] }\end{array}$} & \multicolumn{8}{|c|}{ M50 } & \multicolumn{6}{|c|}{ F5 } \\
\hline & \multicolumn{4}{|c|}{ Driver } & \multicolumn{4}{|c|}{ Passenger } & \multicolumn{3}{|c|}{ Driver } & \multicolumn{3}{|c|}{ Passenger } \\
\hline & \multicolumn{2}{|c|}{ 1990-1999 } & \multicolumn{2}{|c|}{$2000-2010$} & \multicolumn{2}{|c|}{ 1990-1999 } & \multicolumn{2}{|c|}{$2000-2010$} & \multicolumn{6}{|c|}{ 2000-2010 } \\
\hline & 48 & 56 & 48 & 56 & 48 & 56 & 48 & 56 & 40 & 48 & 56 & 40 & 48 & 56 \\
\hline Group & 1 & II & III & IV & V & VI & VII & VIII & IX & $\mathrm{X}$ & XI & XII & XIII & XIV \\
\hline$n$ & 44 & 265 & 48 & 417 & 38 & 192 & 43 & 417 & 10 & 46 & 20 & 10 & 45 & 18 \\
\hline$R$ [\%] & 12.9 & 32.2 & 10.3 & 22.5 & 11.5 & 31.3 & 9.4 & 19.4 & 6.8 & 18.2 & 11.8 & 4.3 & 7.9 & 12.5 \\
\hline$h[\%]$ & 1.8 & 2.5 & 1.8 & 1.5 & 1.8 & 2.5 & 1.8 & 1.5 & 3.0 & 3.0 & 3.0 & 3.0 & 3.0 & 3.0 \\
\hline $\bar{x}[\%]$ & 9.3 & 17.2 & 8.6 & 11.2 & 7.9 & 16.9 & 7.8 & 11.2 & 6.3 & 10.4 & 11.4 & 6.3 & 7.9 & 11.1 \\
\hline Me [\%] & 9.3 & 15.8 & 8.1 & 10.0 & 7.4 & 15.8 & 7.3 & 10.3 & 5.2 & 9.1 & 10.9 & 5.9 & 7.6 & 11.0 \\
\hline Mo* [\%] & 8.6 & 13.8 & 7.7 & 8.7 & 7.6 & 14.0 & 6.6 & 8.6 & 5.0 & 7.8 & 9.8 & 5.5 & 7.3 & 10.7 \\
\hline$s[\%]$ & 3.1 & 6.8 & 2.6 & 4.4 & 3.0 & 6.5 & 2.4 & 3.9 & 2.1 & 4.6 & 3.4 & 1.5 & 2.3 & 3.3 \\
\hline$q_{0,25}[\%]$ & 7.2 & 12.2 & 6.7 & 8.2 & 5.4 & 11.9 & 6.0 & 8.3 & 4.5 & 7.0 & 8.5 & 5.1 & 5.9 & 8.8 \\
\hline$q_{0,75}[\%]$ & 11.6 & 20.7 & 10.4 & 13.1 & 9.1 & 20.4 & 9.2 & 13.4 & 7.5 & 12.2 & 12.9 & 6.9 & 9.9 & 12.9 \\
\hline As & 0.01 & 0.20 & 0.18 & 0.26 & 0.15 & 0.17 & 0.22 & 0.25 & 0.49 & 0.28 & 0.17 & 0.26 & 0.14 & 0.03 \\
\hline Ku & 2.36 & 3.23 & 2.61 & 4.64 & 2.84 & 3.36 & 2.82 & 3.71 & 2.21 & 3.11 & 2.65 & 1.97 & 1.90 & 2.21 \\
\hline
\end{tabular}

*) Mode values of $P_{\text {comb }}$ indicator calculated in accordance with (8). The differences between mode values of $P_{\text {comb }}$ indicator calculated on the basis of mode $H I C_{36}$ and $C_{A c c}$ indicators (from Fig. 11) and acc. to (8) for 9 groups are not higher than 5\% for the rest of the groups (I, II, IV, IX and XI), the differences remaining at the level of $8-12 \%$. 

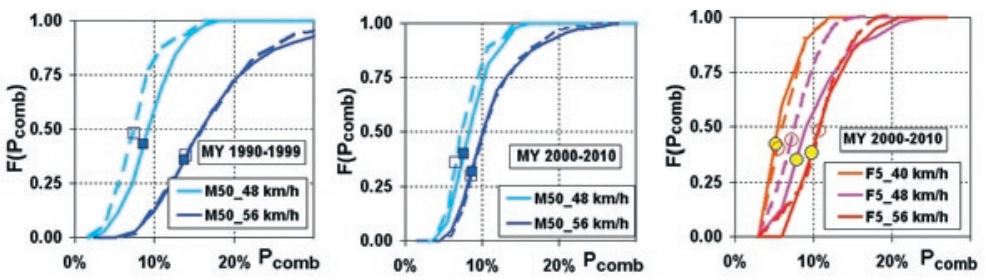

Fig. 12. Distribution functions of the injury risk $P_{\text {comb }}($ AIS4+) of the dummies on the driver's seat (continuous lines) and on the passenger's seat (dashed lines) at the speed with which the car hits the obstacle 40, 48 and $56 \mathrm{~km} / \mathrm{h}$
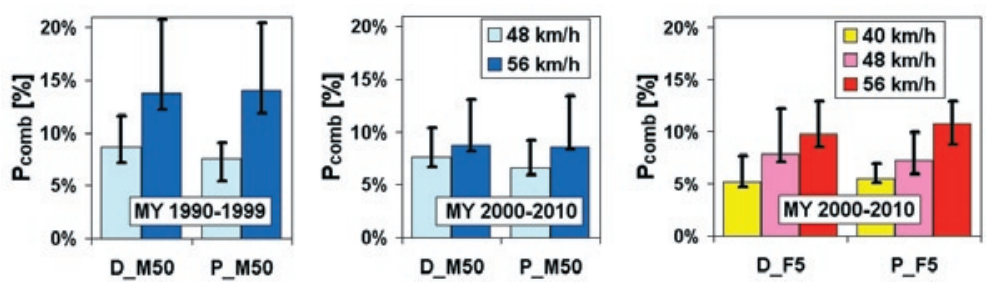

Fig. 13. Mode values of the injury risk $P_{\text {comb }}(A I S 4+)$ for the driver (D) and for the passenger $(P)$ in the case of a car hitting the obstacle at 40,48 and $56 \mathrm{~km} / \mathrm{h}(\mathrm{M} 50$ and F5 dummies)
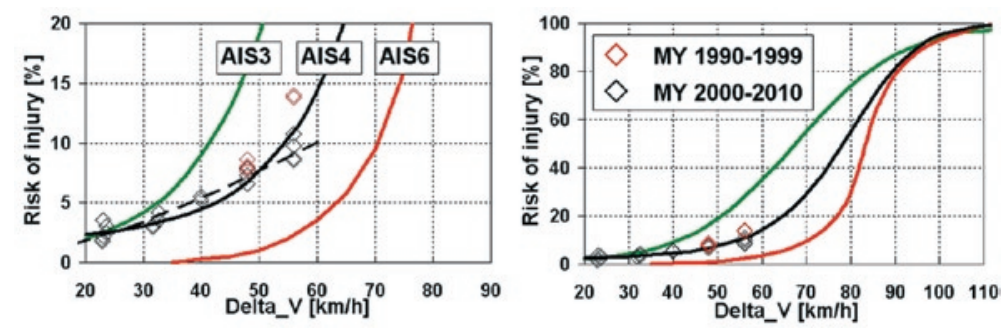

Fig. 14. Risk of injury of the driver and of the passenger on the front seat during a frontal impact as a function of Delta_V(on the left, there is a fragment of the chart from the right); "AIS3" line acc. to [4], "AIS6" line acc. to [23]

significantly higher for F5 dummies on the place of the passengers than on the place of the driver.

\subsection{Effect of the impact speed on the modes of injury risk $P_{\text {comb }}$}

Distribution of the risk of injury $P_{c o m b}$ was assessed also on the basis of histograms. In Table 4, values are presented of the parameters describing the properties of risk $P_{\text {comb }}$ distribution in 14 data groups (I-XIV). On the basis of (6), bin intervals $\mathrm{h}$ were applied of 1.5, 1.8 and $2.5 \%$ for M50 dummy, and $\mathrm{h}=3 \%$ for $\mathrm{F} 5$ dummy.

Distribution in every group is characterised by right-side asymmetry $(A s>0)$, with very weak $(|A s|<0,2)$ or low intensity of the asymmetry $(|A s|<0,4)$. The arithmetical mean is $8-33 \%$ higher than $M o$, and standard deviation $s \in(1.5 \% ; 6.8 \%)$. In case of 5 groups (II, IV, VI, VIII, X) the concentration is higher than in the case of normal distribution $(K u>3)$, and in the rest of the groups $K u \in(1.97 ; 2.84)$.

In Figure 12, distribution functions of risk $P_{\text {comb }}$ are presented, regarding dummies on the seat of the driver and the passenger. The points indicate mode values of injury risk $P_{\text {comb }}$. The modes are located between the quartile $q_{0.25}$ and the median $M e$. What is important is that there are differences of the distribution regarding the driver and the passenger at $48 \mathrm{~km} / \mathrm{h}$ speed.

The mode values of injury risk $P_{\text {comb }}$ (AIS4+) of the driver and the passenger from Table 4 are presented in Figure 13, where the ranges of the variable are marked $\left(\mathrm{Mo}-q_{0.25} ; q_{0.75^{-}} \mathrm{Mo}\right)$, with $50 \%$ of the results in every 14 groups.
On the basis of the mode values of injury risk $P_{c o m b}$, it was discovered that the increase in the speed at which the car hits the obstacle:

from 48 to $56 \mathrm{~km} / \mathrm{h}$ increases the risk of injury (AIS4+) in the case of a 50 -centile man from 8 to $14 \%$ in the cars from 1990-1999 and from 7 to $9 \%$ in the cars from 2000-2010;

from 40 to $56 \mathrm{~km} / \mathrm{h}$ increases the risk of injury (AIS4+) in the case of a 5-centile woman from 5 to $10 \%$ in the cars from 2000-2010.

Generalized results of the analysis of the influence of the speed in case of a frontal impact on the risk of injury for the driver and for the passengers on the front seat are presented in Figure 14. The points on the charts at the speed of 40,48 and $56 \mathrm{~km} / \mathrm{h}$ denote mode values from Figure 13, while points at Delta_V $<40 \mathrm{~km} / \mathrm{h}$ represent the values of the risk of injury $P_{c o m b}$ for the driver and for the passenger, calculated on the basis of the results of two tests with M50 dummy and three tests with F5 dummy (cf. Fig. 7 and tab. 2).

The points on the charts and the behaviour of AIS3 and AIS6 risk functions (lines 6 and 9 in Fig. 1) were used to approximate the results with the following function ("AIS4" line in Fig. 14):

$$
P_{c o m b}(\text { AIS } 4+)=\left\{1+\exp \left[3,9-4,1 \cdot\left(\text { Delta } \_/ 80\right)^{2,3}\right]\right\}^{-1}
$$

where Delta_ $V[\mathrm{~km} / \mathrm{h}]$ is the change in vehicle velocity over the duration of the crash.

The injury risk of the occupants on the front seats of the cars from 2000-2010 during a frontal impact at Delta_ $V<60 \mathrm{~km} / \mathrm{h}$ can be described with the following approximating function (dashed line in Fig. 14):

$$
P_{\text {comb }}(\text { AIS } 4+)=0,017 \cdot \text { Delta_V } V^{1,56}
$$

with a high value of the coefficient of determination $\mathrm{R}^{2}=0,920$.

\section{Summary}

The analysis of the results of several hundred of crash tests made it possible to assess the influence of the impact speed on the injury risk for the driver and for the passenger on the front seat, with their seatbelts fastened and protected with an airbag. The speed of collision is but one of many factors with an influence on the risk of injuries for the occupants of the car. Due to the above, the analysis was conducted in older and newer cars, separately for F5 and M50 dummies and for two different places in the car (on the driver's seat and on the passenger's seat).

The analysis of the injury risk includes the loads on head and chest ( $H_{I C} C_{36}$ i $C_{A c c}$ indicators). Significant dispersion of these indicators made the analysis harder (pt. 5). This is why the values of $H I C_{36}$ and $C_{A c c}$ were determined statistically, by specifying their parameters of distribution. On the basis of the mode values of the risk of injury $P_{c o m b}$, it was determined that the increase in the speed at which the car hits the obstacle from 40 to $56 \mathrm{~km} / \mathrm{h}$ increases the risk of severe injury (AIS4+) in the case of a 5 -centile woman from 5 to $10 \%$. The risk of injury in the case of a 50-centile man was assessed at the collision speed of 48 and $56 \mathrm{~km} / \mathrm{h}$. The increase in speed in such a case increases the risk of severe injury from 8 to $14 \%$ in the cars from 1990-1999 and from 7 to $9 \%$ in the cars from 2000-2010.

To sum up the results - it was determined that the increase in the speed at which the car hits the obstacle from 25 to $56 \mathrm{~km} / \mathrm{h}$ increases the risk of severe injury (AIS4+) for the driver and for the passenger from 2 to $10 \%$. The value of the risk of injury $P_{c o m b}$ is determined by the loads on the chest, irrespective of the speed at which the car 
hits the obstacle. The results of the analysis were used to describe the

\section{References}

1. Cichos D, Otto M, Zölsch S, Clausnitzer S, Vetter D, Pfeiffer G, de Vogel D, Schaar O. Crash analysis criteria description. Arbeitskreis Messdatenverarbeitung Fahrzeugsicherheit. Germany 2011.

2. Dąbrowska-Loranc M, Wojsz T. Prędkość pojazdów w Polsce w 2014 r. Krajowa Rada Bezpieczeństwa Ruchu Drogowego. Warszawa 2014.

3. Funk J R, Cormier J M, Gabler H C. Effect of Delta-V errors in NASS on frontal crash risk calculations. 52nd AAAM Annual Conference Annals of Advances in Automotive Medicine 2008.

4. Gabauer D J, Gabler H C. Comparison of roadside crash injury metrics using event data recorders. Accident Analysis and Prevention 2008; 40: 548-558, http://dx.doi.org/10.1016/j.aap.2007.08.011.

5. Gaca S, Suchorzewski W, Tracz M. Inżynieria ruchu drogowego. WKŁ, Warszawa 2008.

6. Kot S M, Jakubowski J, Sokołowski A. Statystyka. Wydawnictwo Difin SA, Warszawa 2011.

7. Kukuła K. Elementy statystyki w zadaniach. Wydawnictwo Naukowe PWN, Warszawa 1998.

8. Kullgren A. Dose-response models and EDR data for assessment of injury risk and effectiveness of safety systems. IRCOBI Conference, Bern, Switzerland 2008: 3-14

9. Kullgren A, Krafft M, Tingvall C, Lie A. Combining crash recorder and paired comparison technique: Injury risk functions in frontal and rear impacts with special reference to neck injuries. The 18th International Technical Conference on the Enhanced Safety of Vehicles, Paper Number 404, Nagoya, Japan 2003.

10. Liu W C, Doong J L, Tsai S L, Lai C H, Jeng M C. Integrated model of simulated occupant injury risk and real medical costs. Journal of Safety Research 2009; 40: 461-468, http://dx.doi.org/10.1016/j.jsr.2009.09.006.

11. Opportunities exist to enhance NHTSA's New Car Assessment Program. United States Government Accountability Office, GAO-05-370. USA 2005.

12. Pijanowski B, Żardecki D. Selected vehicle monitoring problems with the e-Call system taken as an example. The Archives of Automotive Engineering 2013; 3: 25-41.

13. Prochowski L, Kochanek H. Analiza wieku i obrażeń ofiar wypadków drogowych w aspekcie programowania ratownictwa drogowego. Logistyka 2015; 4: 1082-1090.

14. Prochowski L, Żuchowski A, Zielonka K. Analysis of the influence of the speed of impact against an obstacle on the dynamic loads acting on occupants of an automotive vehicle with body-on-frame design of the load bearing structure. The Archives of Automotive Engineering 2011; 4: 53-73.

15. Prochowski L, Żuchowski A. Analysis of the influence of passenger position in a car on a risk of injuries during a car accident. Eksploatacja i Niezawodnosc-Maintenance and Reliability 2014; 16(3): 360-366.

16. Richards D, Cuerden R. The relationship between speed and car driver injury severity. Road Safety Web Publication No.9, Transport Research Laboratory, Department for Transport, London 2009.

17. Schmitt K U, Niederer P F, Muser M H, Walz F. Trauma biomechanics. Accidental injury in traffic and sports. Springer-Verlag Berlin Heidelberg 2010.

18. Strandroth J, Rizzi M, Kullgren A, Tingvall C. Head-on collisions between passenger cars and heavy goods vehicles: Injury risk functions and benefits of Autonomous Emergency Braking. IRCOBI Conference 2012: 342-351.

19. Symon E. Wypadki drogowe w Polsce (lata 2001-2014), http://statystyka.policja.pl.

20. Vincze-Pap S, Csiszár A. Real and simulated crashworthiness tests on buses. The 19th International Technical Conference on the Enhanced Safety of Vehicles, Washington, 2005.

21. Wicher J. Bezpieczeństwo samochodów i ruchu drogowego. WKŁ, Warszawa 2012.

22. Wicher J. Is it worth limiting the travel speed? The Archives of Automotive Engineering 2015; 69(4): 105-114.

23. Wramborg P. A new approach to a safe and sustainable road structure and street design for urban areas. Proceedings of the Road Safety on Four Continents Conference, Warsaw 2005.

24. www.nhtsa.gov.

25. Żuchowski A. Risk of injury for the front and rear seat passengers of the passenger cars in frontal impact. Journal of KONES Powertrain and Transport 2012; 19(3): 507-518, http://dx.doi.org/10.5604/12314005.1138166.

26. Żuchowski A. The use of energy methods at the calculation of vehicle impact velocity. The Archives of Automotive Engineering 2015 ; 68(2): 85-111.

27. Żuchowski A, Jackowski J. Analysis of properties of operation of the supporting equipment for the seat belts. Journal of KONES Powertrain and Transport 2011; 18(1): 697-704.

28. Żuchowski A, Prochowski L. The analysis of safety of rear seat occupants of a passenger car during the road accident. The Archives of Automotive Engineering 2011; 53(3): 83-98.

29. Żuchowski A, Wicher J. Influence of the pre-tightening of seat belts on the loads acting on rear seat occupants during a frontal collision. The Archives of Automotive Engineering 2013; 2: 93-110, http://dx.doi.org/10.5604/1234754X.1066779.

\author{
Andrzej ŻUCHOWSKI \\ Institute of Motor Vehicles and Transportation \\ Faculty of Mechanical Engineering \\ Military University of Technology \\ ul. Gen. S. Kaliskiego 2, 00-908 Warsaw, Poland \\ E-mail: andrzej.zuchowski@wat.edu.pl
}

